evening, which showed that the upper current had changed to south-east. No observations could be made during the two wet days which followed; but early in the morning of the 27 th, when the centre was about roo miles to the north, true cirri were observed moving slowly from north-east. These soon disappeared; but at $6 \mathrm{p.m}$. of the same day an important change took place, the bands of ice-cloud moving from south-south-west, from which point, or from a little west of it, the belts have continued to travel up to the time of my writing this, the lines being nearly parallel to the isobars, and to the general direction of the surface winds, and precisely resembling in character the stripes seen in most cases travelling from north-north-west when a depression, whose centre has passed a little to the north of the observer, has moved away to north-east. ${ }^{1}$

(3) In an elaborate paper in the Quart. Journ. of the R. Met. Soc. for October I 877 , the writer pointed out that in the extreme left-hand segment of an approximately circular cyclone, moving in any direction in the northern temperate latitudes, the movements of the upper currents are by no means analogous to those in the right-hand segment. ${ }^{2}$ In the case of cyclones travelling eastwards, the reason of this difference is, I think, now well understood. Owing to the great relative density of the lower atmosphere, attended with low barometric pressure, near the poles, the gradients for westerly currents are far more constant in the upper than in the lower strata of the atmosphere in the regions traversed by extra-tropical cyclones. Over a large number of these cyclones, therefore, many of the isobars in the upper regions of the atmosphere do not form closed curves, but curves somewhat resembling those which, at the earth's surface, accompanying what are popularly termed V-shaped depressions. It is a question of the utmost interest whether, during the periods in which depressions travel to the west, the distribution of gradients in the upper atmosphere is really for the time reversed, and, if so, what can be the causes of so remarkable a change. There is a further question correlated with the above, which deserves more attention than has been given to it. The writer long ago pointed out (Journ. Scot. Met. Soc., vol. iv. pp. 333335 ) that in cases of depressions travelling westward across our islands, temperatures at the earth's surface are in general higher over Scandinavia than over France; and a considerable number of instances have occurred since I 875 which have confirmed this conclusion. But in most of these cases an anticyclone has lain to the north-east of us, so that the "gradient force" of the lower strata may have tended to send the depression westwards, in addition to the ascensional force, ass ciated with condensation in the western segment, due to the indraught of relatively warm air from north and north-east. In the instance described in this paper pressure was not particularly high over Scandinavia, during the westward progress of the system, but temperature seems to have been higher, over Sweden at least, than in France.

May 30.

\section{The Crowing of the Jungle Cock.}

IN Nature (vol. xliii. p. 295) Mr. Henry O. Forbes has a letter commenting on a statement of $\mathrm{Mr}$. Bartlett to the effect that the wild jungle cock does not crow, and testifying that he once heard one. In reply, in the next number of NATURE, it was suggested that the cock heard by $\mathrm{Mr}$. Forbes was a hybrid.

I think that no one who has travelled in the jungles of Burma, during the dry season, can have any doubt that the jungle cock crows ; for he cannot fail to have heard them many times.

It so happens that, just after reading Mr. Forbes's letter, I had occasion to travel among the hills which form the watershed between the Irrawaddy and the Sittong rivers. In one region here a large kind of bamboo was seeding, so that the jungle fowl were very numerous, and I heard them crowing in great numbers. I remember one place in particular : the Karens had prepared us a hut in which to sleep just outside of their village, which consisted, like nearly all the villages in these hills, of a single house, each family having its separate room in the common

I These stripes or cirro-filum are so abundant in the rear of most depressions, towards the termination of the inversion disturbances accompanyng squalls or thunder-showers, in Europe and the Northern States that it is singularly unfortunate that the statement of an English meteorologist, to the effect that they do not exist, should have found its way into the first edition of Ferrel's "Popular Treatise on the Winds."

2 See also Ferrel, "Pup. Treat.," \$ 180 ; "Modern Meteorology," p. III (diagram).

NO. I I 29, VOL. 44] building. "At cock crowing" in the morning we had, close to us, the crowing of the village cocks, and on every side, far and near, the answering crows of multitudes of wild birds. I do not remember ever to have been treated to such a chanticleer concert before.

The idea that these wild cocks were all hybrids is inadmissible, because (I) they were so very numerous, and (2) the country is very sparsely peopled, the villages all being small and far apart, and the greater part of the country still covered with primæval forest.

The crow of the jungle cock is shrill, like that of the smallest breeds of domestic fowl, and is, perhaps, a little less prolonged than that of the average domestic cock; but it can hardly be distinguished from the crow of a small breed of fowl kept by the Karens, some individuals of which so closely resemble the wild fowl that they are used as decoys.

I have several times heard wild fowl cackle, and in this journey, while in the midst of a heavy forest, miles from any human habitation, we came upon a flock of wild fowl cackling, and could tell hy the tones that both cocks and hens were cackling. One of the followers being sent with a gun to try and get a shot, some of the birds saw him and flew, whereupon one of the cocks gave the peculiar call which the domestic cock gives when a bird flies over him.

I might add that, among the numerous birds shot in this region, there was one hen which had a pair of spurs about half an inch long.

Rangoon, May 20.

\section{Cordylophora lacustris.}

I $\mathrm{r}$ is generally believed that this tube-dwelling Hydrozoa was originally a salt-water animal, and although now found a considerable distance from tidal water, it still dwells in rivers and canals more or less connected with tidal rivers. I have for many years found it in the Chester and Ellesmere Port Canal, growing principally on the shells of the fresh-water mussel, from two to three miles from the tidal river (the Dee). It seems to be a shade-loving animal, as I have always found it under the bridges, and from 4 to 6 feet ben $3 a t h$ the surface of the water.

The tubes only remain during the winter and early spring, and the animal is fully developed in August and September. It is generally accompanied by Fredericella sultana.

King ley Lodge, Chester, June 12 . ThOMAs SHEPHEARD.

\section{Philosophical Instrument Makers.}

I FIND in your paper of June II (p. I35) that Messrs. Newton and $\mathrm{Co}$. have been appointed philosophical instrument makers to the Royal Institution of Great Britain. Allow me to state that they are not the only ones, and that I also was appointed on June I by the managers of the Royal Institution of Great Britain to be their philosophical instrument maker. I thought that in the interest of the public you should know this fact.

204 Stanhope Street, Hampstead Road, June 12. A. Hilger.

The Earthquake of June 7 .

THE earthquake of June 7 , whose centre seems to have been in the province of Verona, was also perceptible at Basle. The seismometer of the Bernoullianum Observatory registered a horizontal shock at $\mathrm{Ih} .47 \mathrm{~m}$. 29s. a. Basle mean time, which corresponds to Ih. $17 \mathrm{~m}$. Ios. Greenwich mean time.

At Thal, a village east of St. Gall, the shock was strong enough to be felt by several persons.

Basle, June I 3 .

A. RIGGENBACH-BURCKHARDT.

\section{NOTE ON EGYPTIAN IRRIGATION.}

$\mathrm{I}$ entering upon any account of Egyptian irrigation it is necessary, at first, to point out that it consists of two very broad subdivisions: (I) the irrigation effected by the Nile flood when there is rich muddy water in abundance for a land thrice as big as Egypt, and when everyone considers it his absolute right to have his fields 
flooded without the expense or trouble of raising the water artificially; and (2) the irrigation effected by the Nile at its lowest, in those hot months of May and June when the water surface is 20 feet below that of the field, and when it is only by the strictest economy that we can water an area not exceeding one-fourth of the whole of Egypt.

2. The Irrigation of Old Egypt.-The first irrigation is the ancient art of Egypt, the culture that, from the days of the Pharaohs, made this little valley the granary of Europe. The products are wheat, barley, beans, maize, and rice. These two last crops require special irrigation. For the growth of wheat, barley, and beans, it is enough to saturate the fields, during high flood, from August to 1) ctober. The seed is scattered as the waters retreat, and the fields receive neither irrigation nor rain from that time till the harvest is gathered in at the end of April.

3. Perennial Irrigation. - The introduction of the second system is due to the sagacity of Mohamed Ali, who saw that the conditions of soil and climate were such as to favour the growth of cotton and sugar-cane, sub-tropical products greatly exceeding the value of cereals. But these crops require irrigation during the months when the Nile is at its lowest, hence a system of deep canals was necessary, and it was in trying to carry out this system in Lower Egypt that the Egyptians got into hopeless difficulties, for the canals got blocked with silt, and it was most difficult to clear them.

4. The Barrage unused.-The obvious remedy was to raise the water in the river, and divert it into the canals by a Barrage or dam at the apex of the Delta. Such a work was constructed, at a cost of about two millions sterling; but soon after its completion it cracked in a very alarming way, and, from 1867 to 1883 , remained practically useless. The great network of canals continued to be cleared year aíter year to a depth of about 20 feet below the soil, and for half of each year the corvée was constantly employed on them.

5. Pumping.-The Egyptian Government had abandoned all hope of again using the Barrage. They had entered into a contract with a private company to irrigate Behera by a system of pumps, at an annual cost of from $£ 50,000$ to $£ 60,000$; and they were about to come to similar arrangements for the rest of the Delta, at an initial cost of $£ 700,000$, and an annual one of $£ 250,000$.

6. Neglect of Drainage.-Continuous irrigation like that of Lower Egypt requires to be accompanied by drainage, otherwise the land becomes soured and waterlogged. No attention was being paid to this subject in 1883 .

7. State of Upper Fgypt.--The first system of irrigation alluded to above continued to be practised in Upper Egypt. A few very costly bridges had been built to assist it, but little attention was being bestowed on it, and even in years of average Nile flood we found a loss of annual revenue amounting to about $£ 38$,ooo taking place.

8. Addition to Area of Egypt.--Such was the state of affairs when we took charge of the irrigation in 1884 . I am frequently asked whether, since then, there has not been a great addition to the cultivated area of Egypt. My reply is in the negative.

The question of extending cultivation into the desert is partly one of displacement of population, chiefly one of level, for above the point that the Nile. flood can be brought to reach we must not look for an extension of cultivation. Some goes on-notably to the west of the province of Behera and in the Fayoum; but it is not on a very large scale.

9. Reclamation of Marshes.-An extension much more rapid, and of more importance, is in progress along all the north of the Delta, where land is being yearly reclaimed from marsh and lagoon by our drainage operations.

NO. I I 29, VOL. 44]
The cultivated and revenue-paying area of Egypt is about five millions of acres. The lagoons in the north cover an area of about $1,280,000$ acres. I expect in a very few years to see at least half of this land reclaimed and cultivated.

10. The Barrage repaired, and the Effect on Lower Egypt.-What we have done, are doing, and propose to do, then, in future years is as follows:-

First. The Barrage has been completed, and placed in a condition to fulfil its original purpose. From upstream of it are derived three main trunk canals which irrigate the whole Delta, and three smaller canals which irrigate all the country north-east of Cairo and to the south of Zagazig; one of these takes water to Port Said and Suez. The outlay on the Barrage has been, since I 884 , about $£ 460,000$.

Of the three trunk canals, that on the west had been neglected, and completely filled in with sand. It has been restored, and the system of pumps alluded to in paragraph 5 will, I hope, never be used again.

The canal supplying the East Delta (termed the Tewfikieh Canal) has been entirely made since 1886 , at a cost of $£ 372,000$.

Practically, the whole summer supply of the Nile is diverted by the Barrage into these canals, and none flows out useless to the sea. The value of the work is thisthat so long as there is water in the Nile it is under our control, and, however low the river may fall, the water will get on to the fields, and the great cotton crop will be secured. In former days, during low Nile, the canals were left high and dry, and what water there was flowed out to the sea, useless.

The Barrage has not much increased the area of cultivation, but it has very largely increased that of land bearing double crops--that is, the area producing cotton. It was in I 884 that, by employing temporary measures, we began to use the Barrage. Since then, the average annual yield of cotton has been 333,893 kantars ( 15.000 tons) greater than in the five years preceding 1884 . This represents a value to the country of $£ 835,000$ a year, exclusive of the value of cotton-seeds.

11. Provision for Navigation.-Secondly. As the abstraction of water renders impossible the river navigation during four or five months every year, two main canals have been selected, one of them roughly parallel to each of the branches of the Nile, and fitted with locks and rendered navigable. This is not yet quite finished. When it is, it will enable laden boats to pass freely be. tween Cairo and Alexandria on one side, and Cairo and Damietta on the other side, at all seasons of the year. Other locks have been built, and obstructions removed, so that navigation has had an impulse given to it throughout the whole Delta.

I2. Drainage Introduced.-Thirdly. Year by year have been opened out new miles of drainage arteries, and in Behera, Gharbieh, Dakahlieh, Sharkieh in Lower Egypt, and in the Fayoum, large tracts have been reclaimed from salt-marsh, and now yield good crops. The Budget for the current year contains $f_{1440,000}$ for new drainageworks in Lower Egypt. No part of our work has been more appreciated than this, but, unfortunately, the defective system of revenue statistics makes it impossible to say what lands have been reclaimed. The mileage of drains is not less than 1500 .

I3. Measures for Improving Irrigation of Upper Egypt.-Fourthly. I bave said, in paragraph 7 , that there has been an annual loss of about $£ 38$;000 in average years, due to the Nile flood not attaining all the fields of Upper Egypt. In exceptional years this Joss has been much greater. Thus, after the very deficient flood of

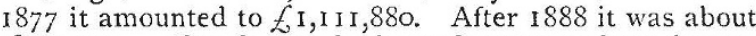
$£ 300,000$. If such was the loss of revenue alone, it may ve imagined what a heavy calamity was inflicted on the 
cultivators. Colonel Ross, Inspector-General of Irrigation, has studied this subject most closely. Even in these deficient years there was water enough in the river if it could only be got on to the land. He has proved that, by a judicious system of canals, sluices, siphons, escapes, weirs, \&c., it may be arranged that, even in the worst years, the whole Nile valley shall receive its share of mud-charged water. This involves the construction of no great work like the Barrage (the most expensive does not exceed $£ 45,000)$, but of a great number of works costing from $f_{5} 5000$ to $f_{15}, 000$ each, requiring very careful designing, and built often in remote spots, where construction of any kind is difficult.

These works have been going on now for more than a year. When finished, as I hope they will be in 1893 , the whole outlay will be about $£ 600$,ooo. And then, I trust, the lands of Upper Egypt will yield their full crop, however defective may be the Nile flood.

14. Agricultural Roads.--Fifthly. A minor subject, and yet one of great value to the country, deserves notice here-namely, the introduction of agricultural roads, This reform is due to Riaz Pasha. Until two years ago. it would have been impossible to take a cart-load of agricultural produce from any one centre of population to another in the Delta. Comparatively few of the canals were adapted for boats, and the one means of transporting cotton to the railway stations or to the river was by camels, which, however well adapted for carrying burdens on the firm sand of the desert, are not suitable for the rich alluvial soil and the sloppy fields of the Nile valley. This is all being changed. The people have willingly accepted a tax never exceeding P.E. 4 or 5 per feddan for one year only, and, with the fund thus raised, a whole network of serviceable roads is being formed sufficiently adapted for this dry climate.

15. Corvée Abolition.-The above paragraphs describe generally the improvements that have been brought about in the last seven years. Second to none is the boon that has been conferred on Egypt in the abolition of the corvée. Previous to 1885 , the whole of the earth-work in the clearance and repairs of canals and embankments was effected by the forced, unpaid, unfed labour of the peasantry. In 1884 this labour amounted to 85,000 men working for 160 days. We were told that this was quite a necessary state of things, that it would be impossible to maintain the irrigation-works otherwise, and that the Egyptian peasant, unlike that of any other country, would not work for wages, and must be forced. We estimated that to redeem this corvée and to pay for all this labour would cost $£ 400,000$. Nubar Pasha, in the face of the greatest financial difficulty and opposition, managed to give an annual grant of $£ 250,000$ for this object. Riaz Pasha, at the end of 1889 , found means of granting the remaining $f, 150,000$, and in 1890 , for the first time perhaps in all history, there was no corvée in Egypt.

16. Canal Legislation.-When we began work here, we were much hampered by the want of any canal legislation, there being no law corresponding to what is found in India, Italy, and elsewhere, treating of the many conflicting questions connected with irrigation. After three years' discussion, a very useful Canal Act now exists, and the only misfortune is that it is not binding on residents of foreign nationality.

17. Storage of Nile Water.-Lastly, as regards our programme for the future, there is abundance to do in carrying out, year by year, solid unpretending reforms; but, besides these, a very large question is coming to the front. The restoration of the Barrage placed at our disposal all the water of low Nile, but the increase in the area irrigated outruns the increase in the water available, and we have to look for means of storing the surplus volume of the flood, and utilizing it when the river is low.

There are two ways in which this may probably be done. The first, which is connected with the name of an

$$
\text { NO. I I 29, VOL. 44] }
$$

ingenious American gentleman, Mr. Cope Whitehouse, is to divert a portion of the flood into a great natural depression existing west of the Nile valley, and there to form a storage reservoir, to be drawn upon as the water in the river decreases. This has been examined and found feasible, but the expense, probably $1 \frac{1}{2}$ millions sterling, is against it. The alternative project is to pond up water in the valley of the river itself above Assouan. This project is being studied at present. There can be hardly any further extension of the cotton cultivation if one or the other of these schemes is not executed. There is room enough in the country to employ both.

COLIN SCOTT MONCRIEFF, Under-Secretary of State, Public Works Department.

Cairo, March 5, r89r.

\section{THE SECOND ORNITHOLOGICAL CONGRESS.}

A FULL report of the proceedings of this important Congress can only be obtained when the official Comptis rendus are published, for the officers of one section were unable to attend the meetings of the other sections owing to the fact that all four sections sat at one and the same time. This is the only complaint we have to make concerning the recent proceedings, but as it affects the future of these useful reunions, we feel compelled to make our protest, because, by the simultaneous session of all the sections of a Congress, no man, however interested in the subjects under discussion, can hear all that he wishes to hear; the visitor has to choose between two meetings, both of which probably possess for him an equal interest. It must be obvious to everyone who had the privilege of attending the second Ornithological Congress that a great gathering of specialists such as that which took place last month must require more time than three days to discuss such varied problems as were placed before them at the recent meeting.

The city of Budapest was happily chosen as the meeting-place of the Congress, and it may well-be questioned whether there is any country in the world that could have offered so many attractions to the ornithologist as Hungary. The hospitality of the Hungarians is proverbial, the accommodation in the beautiful capital is unlimited, and access thereto is easy. After an enjoyable trip down the Danube from Vienna, the travellers found themselves at the opening conversazione of the Congress, which was celebrated in the Grand Hotel "Hungaria." Here the Hungarian Committee had assembled with all the members of the Congress to welcome the guests, and the inaugural banquet served as a pleasant medium for the introduction of the strangers. On May 17 the first general meeting of the Congress took place in the sumptuous theatre of the Hungarian National Museum. After some words of welcome from the Burgomaster of Budapest, the officers for the Congress were chosen as follows :- Honorary Presidents : Count Bethlen, Minister of Agriculture ; Count A. Csáky, Minister of Public Instruction; Mr. B. Kállay, Minister of Finance. Presidents: Prof. Victor Fatio (Geneva) and Mr. Otto Herman, M.P. Vice-Presidents : Dr. Rudolph Blasius (Brunswick), Prof. S. Brusina (Agram), Prof. R. Collett (Christiania), Mr. J. de Csató (Budapest), Dr. Otto Finsch (Bremen), Major Alex. von Homeyer (Greifswald), Dr. A. B. Meyer (Dresden), Dr. E. von Middendorf (Livonia), Dr. Emil Oustalet (Paris), Dr. Bowdler Sharpe (British Museum), Mr. E. von Szalay (Budapest), Victor Ritter Tschusi von Schmidhoffen (Hallein). General Secretary : Dr. G. von Horváth. Secretaries: Mr. E. Chernel von. Chernelháza, Dr. A. Lendl, Dr. L. Lorenz von Liburnau, Dr. A. Lovassy, Dr. I. von Madarász, Mr. O. Reiser, Prof. G. Szikla. Hon. Secretaries: Mr. E. de Gaál, Mr. B. de Lipthay, Mr. J. d'Ottlik. Quæstor: Mr. J. von 